ПОТЕНЦІАЛ СУЧАСНИХ ТРЕНДІВ ХАРЧУВАННЯ

ТА РЕГІОНАЛЬНИХ БРЕНДІВ ХАРЧОВИХ ПРОДУКТІВ У РОЗВИТКУ ВІТЧИЗНЯНОї ТУРИСТИЧНОї ІНДУСТРІЇ

\title{
POTENTIAL OF MODERN SUPPLY TRENDS AND REGIONAL BRANDS OF FOOD PRODUCTS IN THE DEVELOPMENT OF DOMESTIC TOURIST INDUSTRY
}

УДК 338.48

https://doi.org/10.32843/bses.50-32

\section{Захарчин Р.M.}

к.е.н., доцент кафедри підприємництва, товарознавства та експертизи товарів Львівський інститут економіки і туризму

\section{Zakharchyn Roman}

Lviv Institute of Economics and Tourism

\begin{abstract}
Гастрономічний туризм - це різновид туристичної галузі, що знайомить з кулінарними традиціями народів світу. Серед сучасних трендів у ссрері харчування активізується рух локаворства. У статті розглянуто можливості цього досвіду у вітчизняному туристичному підприємництві. Механізм захищених географрічних зазначень існує в країнах, які вважають його дієвим для захисту національних продуктів і виробників. 3 огляду на сучасні тренди харчування, вимоги до послуг у гастрономічному туризмі розглянуто рух локаворства і механізм географрічних зазначень продуктів як потенціал інноваційного розвитку туристичної індустрії в регіонах країни. Висвітлено переваги вирощування та реалізації місцевої їжі. Акцентовано увагу на необхідності активізації процесів створення національних продуктів зі статусом геограсрічних зазначень, їх маркетингового супроводу задля формування привабливого іміджу регіонів.

Ключові слова: гастрономічний туризм, тренди харчування, місцеві бренди, потреби споживачів, локаворство, географрічні зазначення, соціально-економічний розвиток регіонів.
\end{abstract}

Гастрономический туризм - это разновидность туристической отрасли, кото- рая знакомит с кулинарными традициями народов мира. Среди современных трендов в сорере питания активизируется движение локаворства. В статье рассмотрены возможности этого опыта в отечественном туристическом предпринимательстве. Механизм защищенных географических указаний существует в странах, которые считают его действенным для защиты национальных продуктов и производителей. С учетом современных трендов питания, требований к услугам в гастрономическом туризме рассмотрены движение локаворства и механизм географических указаний продуктов как потенциал инновационного развития туристической индустрии в регионах страны. Освещены преимущества выращивания и реализации местной пищи. Акцентировано внимание на необходимости активизации процессов создания национальных продуктов со статусом географических указаний, их маркетинговом сопровождении с целью формирования привлекательного имиджа регионов.

Ключевые слова: гастрономический туризм, тренды питания, местные бренды, потребности потребителей, локаворство, географические указания, социально-экономическое развитие регионов.

Gastronomic tourism is distinguished as one of the types of tourism industry, what allows to become acquainted with culinary traditions of various cuisines of the world which contain some specificities of the raw materials used, the technology of production, some methods of serving and consumption. Moreover, gastronomic tourism provides the opportunity to learn deeply about the concrete country, its regions, some local features of which have an impact on the culture and the traditions of consumption. Among the other modern trends of production and consumption of food, the locavorism movement is starting to gain interest. The article reviews the opportunities of the impact and the practical use of this experience on the operation of domestic tourism businesses. The utilization of protected geographical indications has found its effective use in world countries which consider this mechanism being an efficient way to protect national products, brands and manufacturers. Geographical indications, as which can also be seen local food, thanks to their creativity, unique characteristics, the signs of authenticity and belonging to cultural-historical inheritance, the lifestyle of individual regions, areas, ethnicities are capable not only of protection of "the authorship", but also attraction of consumers, tourists, stimulation of the development of individual areas as a whole. Taking into account the existing world experience as well as the trends in food industry and the requirements of modern consumers regarding the services in tourism industry, the article illustrates the locavorism movement and the mechanism of geographical indications of the products as a capability of innovative development and increasing the competitiveness of domestic tourism industry in country's regions. There are proposed some ways to use the advantages of cultivation and realization of local foods both for local consumers and tourists. The attention is paid to the importance of activation of the processes of the creation of the national products with the status as geographical indications, their modern marketing accompaniment and positioning in order to form the attractive image of the regions, attention to their historical inheritance and modern accomplishments.

Key words: gastronomic tourism, food trends, local brands, requirements of consumers, locavorism, geographical indications, social-economic development of the regions.

Постановка проблеми. Актуальність статті зумовлена гострою потребою туристичної галузі у впровадженні інноваційних фрорм ведення бізнесу, що покликано забезпечити його ефективність та стабільний розвиток. Ці фрорми повинні враховувати сучасні світові тренди у сорері харчування, харчових продуктів, які становлять основу гастрономічного туризму. 3 огляду на зростаючу популярність у споживачів, туристів продуктів місцевого виробництва 3 унікальними етнічними та автентичними ознаками, що декларує своєю сутністю локаворство, а також інтеграцію України до європейських вимог щодо захисту національних продуктів через механізм геограсрічних зазначень постають нагальними потребами дослідження, аналіз та запровадження в практику туристичного бізнесу цього досвіду.

Аналіз останніх досліджень і публікацій. Аспекти розвитку гастрономічного туризму мають місце в дослідженнях таких вітчизняних та закордонних учених, як В.Г. Антоненко, Т.І. Божук, О.А. Борисюк, В.В. Корнілова, Н.В. Корнілова, Р. Мітчелл, К. Холл. Проблематика фрормування трендів на світовому ринку харчування та в туризмі відображена в працях таких учених, як Л.І. Крикавський, 
І.М. Куліш, А.Л. Зиновенко, Н.Н. Шматко. Питання інноваційної діяльності у сорері послуг харчування розглянуто в дослідженнях О.В. Борисової, Н.М. Григоренко, Т.І. Кононенко та інших науковців. Водночас сучасним трендам вирощування та споживання місцевих продуктів харчування (локаворство) та запровадженню механізму географрічних зазначень продуктів, їх значенню в розвитку гастрономічного туризму приділено незначну увагу.

Постановка завдання. Метою статті $є$ розкриття потенціалу сучасних світових трендів харчування в розвитку гастрономічного туризму окремих регіонів України, висвітлення можливих шляхів використання руху локаворства та механізму географрічних зазначень продуктів, як чинників ефективного розвитку та підвищення конкурентоспроможності цього виду вітчизняної туристичної індустрії.

Виклад основного матеріалу дослідження. Віддавна природним бажанням населення кожної країни, краю, регіону, іншої географрічної одиниці є прагнення як територіального. так і особистісного благополуччя, достатку, затишного облаштування проживання та побуту. В сучасному глобалізованому світі 3 його інтеграційно налаштованим населенням за сучасних засобах комунікації, а також наявних фрінансових можливостях багатьох потужним чинником пізнання сьогодення в історичному, національному, географрічному, культурно-мистецькому, індустріальному та інших численних аспектах постає галузь туризму. Привабливість туризму, його послуг залежать від численних фракторів, але перш за все, на нашу думку, від споживача. Нові виклики внаслідок трансформаційних процесів у суспільній свідомості, підприємницькому русі, галузях господарювання, інформаційному просторі привели до появи істотно нового сучасного типу споживача. Його вирізняють нові потреби, їхні пріоритети, осучаснене сприйняття й оцінювання, нові бачення доцільності, престижності, нові очікування від використання тощо.

Досвід показує, що провідні позиції підприємців в будь-якій сорері діяльності зумовлені увагою, підтримкою та відповідністю сучасним тенденціям, трендам просрільного ринку.

Однією із складових послуг туризму, яка претендує на таку собі універсальну послугу, в якій зацікавлені практично всі подорожуючі, яка значною мірою може посприяти туристичній привабливості місця відвідин, $є$ харчування в широкому розумінні цього слова, що включає продукти, сировину, технологію приготування, страви, рецептуру й, звичайно, якість та безпечність, а з розвитком трендів і вимог сучасного споживача до цих якостей додаються інорраструктура закладів ресторанного господарства, підготовленість персоналу, унікальність харчової продукції та місцевих традицій приготування й споживання страв.

Питання організації харчування в туризмі не варто применшувати чи розглядати у вузькому діа- пазоні розуміння. Воно вимагає глибокого та всебічного підходу з огляду не тільки на суто гастрономічний аспект, але й на соціально-економічний, природно-кліматичний, історико-краєзнавчий, підприємницький, маркетинговий тощо. Ефективний розвиток туристичної галузі в Україні, її регіонах вимагає динамічного реагування на запити сучасного споживача, отже, оперативного аналізу й контролю за відповідністю, своєчасністю та привабливістю послуг, які надаються.

Дбаючи про інноваційний розвиток економіки, моделюючи оптимальні шляхи вдосконалення та осучаснення діяльності в будь-якій сорері, зокрема в гастрономічному туризмі, вважаємо, що вкрай необхідно ознайомлюватися $з$ уже наявним досвідом, брати на озброєння новітні підходи, практики, актуальні тренди, що принесли або приносять комерційний чи соціальний успіх. «Поглиблене вивчення основних світових тенденцій розвитку гастрономічного туризму дасть змогу використати їх для практики розбудови вітчизняного туристичного ринку. В перспективі це сприятиме покращенню туристичного іміджу країни та зростанню туристичних потоків» [1].

Визначаючи глобальні тренди розвитку туризму, науковці та провідні фрахівці галузі виокремлюють територію як «основу гастрономічних пропозицій», отже, як вважають В.В. Корнілова та Н.В. Корнілова, «перетворення територій на кулінарний ландшафт $є$ однією із проблем туристичних дестинацій». Ті ж автори зазначають, що основою гастрономічного туризму є продукт, тому важливо визначити, які ресурси ми будемо перетворювати на туристичний продукт, що дасть змогу ідентифікувати цю територію [1].

Як такі потенційно успішні підходи, що співзвучні із сучасними трендами у сорері харчування, харчових продуктів, гастрономічному туризмі, розглянемо локаворство та географрічні зазначення продуктів.

Кожна країна, край, регіон пишається своїми надбаннями в різних сорерах, відповідно, підтримує ці надбання, розвиває, адаптує до сучасності та популяризує. Благодатним ґрунтом для такої популяризації є туризм, тобто сорера, яка знайомить, зближує, об'єднує. Подорожуючи чи прибуваючи $з$ конкретною метою в іншу місцевість, люди зазвичай першочергово цікавляться місцевими брендами (географрічні чи історико-мистецькі, товари чи послуги). Не є винятком у цьому зацікавленні харчові продукти й послуги харчування.

Забезпечення комерційного успіху, а також ефрективне просування послуг харчування в туристичній сфрері багато фрахівців пов'язують із трендом локаворства. Відомо, що цей термін з'явився відносно недавно (2005 рік), але швидко знайшов зацікавлення та підтримку руху локаворів у багатьох країнах світу. Це зацікавлення та підтримку можна пояснити сутністю тренду, яка полягає в пропозиції споживання продуктів харчування, які вирощені 
в конкретній місцевості на максимально близькій відстані від споживача. Привабливість та певна популярність тренду аргументуються локаворами такими чинниками, як повна відповідність санітарногігієнічним нормам; зростаюче число продукції із сертифікатом органічної; відсутність потреби тривалого переміщення на великі відстані, що зберігає якість, свіжість продукції; можливість на власні очі побачити процеси вирощування, виробництва, приготування, подачі до споживання; сприяння фрормуванню культури здорового харчування, кулінарного просвітництва; розвиток вузької спеціалізації та поява мереж спеціалізованих закладів (ресторани, кафе, бари, магазини тощо). Тренд локаворства розвивається й знаходить все більше прихильників. Це можна пояснити не тільки інтересом туристів, подорожуючих, які перш за все шукають місцеві бренди, зокрема харчові, але й рухом локаворів, як вважає І.М. Куліш. Науковець висловлює таку думку, 3 якою ми абсолютно погоджуємось: «вирішує відразу кілька проблем: забезпечує споживачів якісними продуктами харчування, максимально сприяє розвитку невеликих фрермерських господарств, фермерських ринків і забезпечує розвиток локальних сільських територій» [2, с. 118]. Варто спробувати підприємцям, представникам малого бізнесу відкривати заклади ресторанного господарства, хай невеликі, концептуально не претензійні за архітектурою, інтер'єром, оснащенням, меню тощо, проте суто автентичні, що реально реалізують свою концепцію локаворства на місцевій сировині, логічно й уміло адаптованій до специфріки місцевих традицій, кухні, страв, способів приготування. Необхідно всіляко рекламувати, демонструвати переваги локаворства туристам. Зокрема, слід приваблювати самобутністю, можливістю відчути своєрідність краю, торкнутися його історії та кулінарних традицій; екологічністю, безпечністю та іншими ознаками тренду здорового харчування; з умілим використанням трендсеттінгу шляхом залучення до реклами харчової продукції чи характерних закладів ресторанного господарства відомих постатей цієї місцевості або відгуків знаменитостей, які знайомилися 3 локаворством і мають про це позитивні посили; приваблювати спеціальними івентами, організацією подій (свят, фрестивалів, ярмарків, тощо), на яких можна популяризувати локаворство, у продуманому інстальованому вигляді представляти місцеві харчові бренди, привертати увагу туристів та водночас здійснювати гастрономічне просвітництво й заохочувати населення до вирощування та використання місцевої продовольчої сировини.

Визначаючи роль локаворства, сучасні дослідники стверджують, що «локальна мережа продуктів харчування передбачає налагодження відносин між виробниками, дистриб'юторами, роздрібними торгівцями і споживачами у певному місці, де вони працюють разом, щоб підвищити продовольчу без- пеку і забезпечити економічну, екологічну і соціальну стійкість суспільства» [3, с. 48]. $€$ підстави стверджувати, що тренд локаворства спроможний не тільки відіграти важливу роль у процесах зростання ефрективності туристичної індустрії конкретних регіонів, але й постати вагомим чинником процесу місцевого соціально-економічного розвитку самих регіонів загалом. Ми погоджуємося з твердженням науковців про те, що «місцевий соціальноекономічний розвиток (МСЕР) - це процес зміцнення конкурентної позиції міста та активізації його економічного зростання, підвищення добробуту, створення робочих місць, залучення інвестицій та підвищення якості життя». Стабільний МСЕР дає можливості працевлаштування економічно активного населення в регіоні, є основою для підвищення добробуту місцевих мешканців, сприяє підвищенню якості життя на всій території країни [4, с. 46].

Відома позитивна роль у розвитку туризму, підвищенні привабливості та конкурентоспроможності туристичних дестинацій товарних брендів, особливо якщо вони мають локальний характер та відображають місцевий колорит. Сьогодні на основі міжнародного досвіду створені хороші передумови фрормування власних товарних брендів. Асоціація з ЄС дала Україні, її галузям господарства, підприємцям, малому бізнесу, приватному сектору нові можливості. Візьмемо до уваги той фракт, що у вересні 2017 року було створено проєкт ЄС «Підтримка розвитку системи географрічних зазначень», який діє спільно 3 Міністерством аграрної політики та продовольства України, Міністерством економічного розвитку України, бізнес-асоціаціями та асоціаціями споживачів. Цей проєкт підсилює наші зобов'язання в рамках асоціації з ЄС не використовувати європейські географічні зазначення та реєструвати власні. За визначенням, згідно зі статтею 22 Угоди про торговельні аспекти прав інтелектуальної власності (TRIPS), географрічними зазначеннями є такі зазначення, які визначають товар як такий, що походить з території члена, регіону або району цієї території, коли певна якість, репутація або інші характеристики товару значною мірою пов'язані з його географрічним походженням [5]. За своєю сутністю географрічне зазначення - це особливе позначення, яке свідчить про певні унікальні властивості чи характеристики, репутацію, високу якість, певну сировину або традиційне виробництво, які можуть бути притаманні лише тому товару, який походить із певного географрічного регіону. Досвід країн ЄС демонструє, що товарна продукція, зокрема харчові продукти, які марковані як географрічне зазначення, створюють виокремлений сегмент на ринку, а також приваблюють споживачів не тільки до цієї продукції, але й до конкретних місцевостей регіонів загалом. Звідси, як вважають експерти, випливає, що важливими завданнями $€$ осучаснення вже наявної системи та створення нової дієвої системи географрічних зазначень, яка б 
стимулювала та підтримувала внутрішній ринок традиційної продукції [6].

Ще одними важливими завданнями, відповідно угоди про Асоціацію з ЄС, $є$ гармонізація Україною свого законодавство щодо географрічних зазначень 3 європейським та забезпечення належного рівня правової охорони для географрічних зазначень $€ C$. Тут уже зроблено відповідні кроки, оскільки президент України у жовтні 2019 року підписав Закон «Про внесення змін до деяких законодавчих актів України щодо вдосконалення правової охорони географрічних зазначень» (№ 123-IX), ухвалений Верховною Радою 20 вересня (законопроєкт № 1065).

Сир «Гуцульська овеча бриндзя» став першим українським товаром, який отримав свідоцтво про реєстрацію географрічного зазначення. Його видало Міністерство розвитку економіки, торгівлі та сільського розвитку України 11 листопада 2019 року. «Гуцульська овеча бриндзя» - це перше українське географрічне зазначення, що відповідає всім європейським вимогам до реєстрації та має право на визнання в ЄС.

Чи можливо ефективно використовувати механізм захищених географрічних зазначень в Україні, що він дасть вітчизняним виробникам, підприємцям чи місцевим жителям територій? Практичний досвід свідчить про те, що за відособленого позиціонування товарів під географічними зазначеннями і товарів, які ніяким чином не пов'язані, споживачі зазвичай віддають перевагу товарам, виготовленим у певній місцевості, регіоні. Це дуже добре «вписується» в стратегію туристичної галузі, оскільки туристів насамперед цікавить щось конкретне для місця їхньої подорожі чи відпочинку, тому ознакою або чинником «місцевий», «автентичний», «унікальний» доцільно скористатися для привернення уваги, підвищення привабливості та конкурентоспроможності. «Для того щоб найбільш еорективно використовувати зареєстровані географрічні зазначення, необхідно буде активно просувати продукцію, марковану відповідним чином, шляхом інфрормування споживачів про зареєстровані географічні зазначення та про характеристики продукції (ії якість та репутацію), а також шляхом ії рекламування. При цьому дуже важливо, щоб географічні зазначення не сприймалися споживачами самі по собі, а лише у поєднанні з певною продукцією» [7]. Експерти вважають, що ключовими перевагами такого брендингу географрічних зазначень $є$ надання достовірної інформації щодо справжнього територіального походження товарів та можливість уникнути введення туристів-споживачів в оману. Окрім цього, вітчизняним виробникам, підприємцям, бізнесменам необхідно враховувати, що після завершення перехідного періоду вступає в дію заборона на використання захищених законом географрічних зазначень продуктів. Так, наприклад, згідно з вимогами Угоди про асоціацію з ЄС та Закону «Про пра- вову охорону геограсрічних зазначень», після 31 грудня 2022 року, тобто після завершення терміну перехідного періоду, українським виробникам буде заборонено називати своїми сири фета, пармезан, рокфор, а з 2025 року настає заборона використовувати 13 найменувань алкогольної продукції, зокрема коньяку, шампанського, бордо, кальвадосу, к'янті, хересу. Отже, українським виробникам необхідно на серйозному рівні зайнятися пошуком, розробленням, осучасненням, певною мірою інтелектуалізацією найменувань своєї продукції.

Стосовно нашого першого продукту, що має статус географічного зазначення, а саме «Гуцульської овечої бриндзі», то експерти впевнені в тому, що для місцевого бізнесу це матиме таку перевагу, як виведення продукту на загальнонаціональний і європейський ринок, що зумовить додаткові прибутки, доповнить яскравий карпатський колорит автентичним харчовим продуктом 3 давньою історією, що завжди приваблювало туристів, стимулюватиме відновлення вівчарства, фрормування фермерського руху та підприємницької ініціативи місцевого населення. На прикладі «Гуцульської овечої бринзи» можна простежити, яким чином це працює, яка історія, які аргументи разом із якісними показниками можуть посприяти успішному брендуванню та просуванню продукту на ринку, зокрема в туристичному бізнесі. Зона вироблення бринзи - це етнічна Гуцульщина, тобто всі високогірні райони Закарпаття, шість районів ІваноФранківщини та три райони Чернівеччини. Позиціонуючи цей продукт, виробники мають створювати відповідний інформаційний фон, доводити історію, яка полягає в тому, що місцеві мешканці (гуцули) зберегли традицію літнього випасання отар на висоті вище 700 метрів. На такій висоті, а також за мінливих природних умов тільки високогірна карпатська вівця може давати молоко, що забезпечує відповідні параметри сиру. Окрім цього, традиційні виробники бринзи знають, що її якість сильно залежить від погоди, гірських трав та навіть, як стверджують гуцули, від енергетики та настрою чабанів. Акцент на автентичності, екологічності, унікальності географрічного зазначення «Гуцульська овеча бриндзя», його правова захищеність повинні вигідно виокремити цей продукт, засвідчити відмінність від схожих аналогів (наприклад, усі розсільні бринзи, що реалізують у нас супермаркети, чи виготовлена в Польщі бринза «Podhalanska» («Подгалянська»), яка також має географрічне зазначення).

Серед інших сучасних глобальних трендів розвитку гастрономічного туризму фрахівці туристичної галузі виокремлюють співпрацю. На їхню думку, необхідно, щоб усі особи, які працюють у туристичній дестинації, брали участь у створенні туристичного продукту гастрономічного туризму [8, с. 63]. Отже, однією 3 важливих передумов ефективного використання геограсрічних зазначень $€$ створення колективних 
організацій (асоціацій), які «синергують» зусилля основних суб'єктів, що будь яким-чином причетні до продукції зі статусом географрічного зазначення.

Висновки з проведеного дослідження. Задля подальшого розвитку вітчизняної туристичної галузі з огляду на вищенаведені приклади трендів у сорері харчування, на нашу думку, доцільно активніше впроваджувати в практику туристичної діяльності, точніше, її різновиду, яким є гастрономічний туризм, потенціал та світовий досвід локаворства в Україні; розширювати рух локаворів як передумову створення місцевих територіальних (локальних) харчових брендів; без заперечення в хорошому розумінні слова «експансію чужого», розвивати й збагачувати своє, місцеве; стимулювати разом із традиційними закладами ресторанного господарства «локаворські», але так, щоб вони не були «декларативними» й не тільки відрізнялися оригінальними вивісками, але й відповідали суто місцевому колориту зовнішніми декораціями та внутрішнім змістом.

Вищезазначені приклади щодо географрічних зазначень продуктів, на нашу думку, покликані привернути увагу як на загальнодержавному, так і на місцевому територіальному рівнях до потенціалу цього сучасного тренду. Для споживачів туристичних послуг та широкого загалу громадян окреслені шляхи збагатять світогляд, сприятимуть підвищенню рівня гастрономічної обізнаності, поглиблять знання і про імпортовану харчову продукцію, і про національну, пов'язану з конкретними місцевостями та їх традиціями. Все це працюватиме на розвиток регіонального гастрономічного туризму, стимулюватиме створення спеціалізованих асоціацій виробників і споживачів, буде заохочувати до розширення переліку вітчизняних охоронюваних географрічних зазначень, що в сукупності розвиватиме в економічному та соціальному аспектах регіони України.

Беручи до уваги актуальність та вагу місцевого економічного зростання, що створює нові перспективи залучення інвестицій, нові можливості працевлаштування для мешканців регіону, сприяє підвищенню їх добробуту та зростанню підприємницької ініціативи економічно зацікавлених громадян, вважаємо, що використання практики та досвіду вищезазначених трендів провадження гастрономічного туризму є цілком очевидним і доцільним. Туризм, гастрономічний туризм, інноваційні форми його організації здійснять свій вагомий внесок у місцевий соціально-економічний розвиток у широкому розумінні цього процесу, що поєднує матеріальну й духовну складові частини, а саме історичну спадщину, культурно-побутове просвітництво, шану традиціям та інші аспекти життєдіяльності різних регіонів України.

\section{БІБЛІОГРАФІЧНИЙ СПИСОК:}

1. Корнілова В.В., Корнілова Н.В. Сучасні тенденції розвитку гастрономічного туризму. Ефрективна еконо- міка. 2018. № 2. URL: http://www.economy.nayka.com.ua/ ?op=1\&z=6112 (дата звернення: 02.03.2020).

2. Куліш І.М. Вплив новітніх тенденцій виробництва і споживання продуктів харчування на конкурентні переваги сільських територій. Регіональна економіка. 2016. № 2. С. 112-120.

3. Dunnea J.B. Chambersa K.J. Giombolinia and others. What does local' mean in the grocery store? Multiplicity in food retailers' perspectives on sourcing and marketing local foods. Renewable Agriculture and Food Systems. 2011. Vol. 26. Iss. 1. P. 46-59.

4. Ємець О.І., Коржик О.М. Місцевий соціальноекономічний розвиток в умовах глобальної економіки. Наука III тисячоліття: пошуки, проблеми, перспективи розвитку : матеріали I Всеукраїнської науково-практичної інтернет-конореренції (20-21 квітня 2017 року. Бердянськ : БДПУ, 2017. Ч. 1. С. 45-47.

5. Угода про торговельні аспекти прав інтелектуальної власності. URL: https://zakon.rada.gov.ua/laws/ show/981_018 (дата звернення: 02.03.2020).

6. Коваль М.В. Заробити на імені: чи допоможе українському експорту захист географрічних зазначень. Європейська правда. URL: https://www. eurointegration.com.ua/experts/2019/05/13/7095935 (дата звернення: 02.03.2020).

7. Global Report on Food Tourism. World Tourism Organization (UNWTO), Madrid, Spain. 2012. P. 63.

\section{REFERENCES}

1.Kornilova, V.V. and Kornilova, N.V. (2018), Suchasni tendentsii rozvytku hastronomichnoho turyzmu [The modern trends of gastronomic tourism development]. Efektyvna ekonomika, [Online], vol. 2, Available at: http://www.economy.nayka.com.ua/?op=1\&z=6112 (accessed: 2 March 2020).

2. Kulish, I.M. (2016), Vplyv novitnikh tendentsij vyrobnytstva i spozhyvannia produktiv kharchuvannia na konkurentni perevahy sil's'kykh terytorij, [Influence of modern tendencies of food production and consumption on rural territories' competitiveability]. Rehional'na ekonomika, no. 2, pp. 112-120.

3. Dunnea, J.B., Chambersa, K.J. (2011) Giombolinia and others. What does local mean in the grocery store? Multiplicity in food retailers' perspectives on sourcing and marketing local foods. Renewable Agriculture and Food Systems. Vol. 26. Iss. 1. P. 46-59.

4. Yemets', O.I., Korzhyk, O.M. (2017) Mistsevyj sotsial'no-ekonomichnyj rozvytok v umovakh hlobal'noi ekonomiky. [Local socio-economic development in the global economy] Nauka III tysiacholittia: poshuky, problemy, perspektyvy rozvytku: materialy I Vseukrains'koi naukovo-praktychnoi internet-konferentsii (20-21 kvitnia 2017 roku). Berdians'k: BDPU. Vol. 1, pp. 45-47.

5. Uhoda pro torhovel'ni aspekty prav intelektual'noi vlasnosti [Trade-Related Aspects of Intellectual Property Rights]. URL: https://zakon.rada.gov.ua/laws/ show/981_018 (accessed: 2 March 2020).

6. Koval', M.V. (2019). Zarobyty na imeni: chy dopomozhe ukrains'komu eksportu zakhyst heohrafichnykh zaznachen'. Yevropejs'ka pravda. URL: https://www. eurointegration.com.ua/experts/2019/05/13/7095935 (accessed: 2 march 2020).

7. Global Report on Food Tourism (2012). World Tourism Organization (UNWTO), Madrid, Spain. P. 63. 